\title{
Assessment of monthly variation in heavy metal characteristics of Electroplating industrial untreated wastewater at selected sites of Chandigarh
}

\author{
Vivek Pandey* \\ GNA University, Sri Hargobindgarh, Phagwara-Hoshiarpur Road, Phagwara -144405 \\ (Punjab), India

\section{K. Rattan} \\ GNA University, Sri Hargobindgarh, Phagwara-Hoshiarpur Road, Phagwara -144405 \\ (Punjab), India
}

*Corresponding author. Email: pandey_vivekcpcc@rediffmail.com

\section{Article Info}

https://doi.org/10.31018/

jans.v13i1.2527

Received: January 22, 2021

Revised: March 3, 2021

Accepted: March 7, 2021

\section{How to Cite}

Pandey, V. and Rattan, V. K. (2021). Assessment of monthly variation in heavy metal characteristics of Electroplating industrial untreated wastewater at selected sites of Chandigarh. Journal of Applied and Natural Science, 13(1): 250 - 257. https:// doi.org/10.31018/jans.v13i1.2527

\begin{abstract}
With the contest of urbanization and industrial development, electroplating industries have grown rapidly. The different chemicals, metal salts and discharge of large volume of wastewater with inefficient treatment facilities had created the pollution load on water bodies. The present study was carried out to investigate the assessment of the monthly variation of $\mathrm{pH}$ and heavy metals $(\mathrm{Cr}, \mathrm{Ni}, \mathrm{Zn}, \mathrm{Fe})$ of electroplating untreated industrial wastewater from the selected study sites viz. SS-1: Atul Industries, SS-2: Suresh Fasteners, SS-3: Bajrang Industrial Company, SS-4: Stylex Industries, SS-5: Karan Industries, SS-6: Avon Industries, SS-7: Geetika Enterprises, SS-8: Atop Fasteners, SS-9: Accufit Fasteners and SS-10: Ashoka Furniture Udyog at industrial area phase I and phase II of Chandigarh. The untreated electroplating wastewater samples were collected from ten study sites (SS-1 to SS-10) and were analyzed following the standard methods for the examination of water and wastewater. The results of the present study revealed that the maximum concentration of heavy metals such as $\mathrm{Zn}(122.20 \mathrm{mg} / \mathrm{l}) \mathrm{during}$ the month of August 2019 at the SS-8, Ni (156.37 mg/l) during the month of August 2019 at the SS-4, $\mathrm{Cr}(467.01 \mathrm{mg} / \mathrm{l})$ during the month of October 2019 at the SS-5 and Fe (13.22 mg/l)during the month of December 2019 at the SS-2. The load of metallic ions discharge from the electroplating industries before any treatment from the selected study sites (SS-1 to SS-10) was found in the following order as $\mathrm{Cr}>\mathrm{Ni}>\mathrm{Zn}>\mathrm{Fe}$. Thus the present study would provide baseline data for the development of treatment strategies for wastewater discharge from electroplating industries and also in minimizing the effects of heavy metal contamination of receiving water bodies.
\end{abstract}

Keywords: Chemical precipitation, Electroplating, Heavy metal, Hexavalent chromium, Wastewater treatment

\section{INTRODUCTION}

Metal pollution is of great concern as these hazardous pollutants are accumulated in living organisms, including plants, animals, microorganisms, human and environment and cause harmful effects due to their nondegradability (Hashem and Abed, 2002, Kanoun-Boule et al., 2009). Due to the scarcity of clean water, the availability of freshwater is one of the challenging issues to mankind around the world. The water bodies such as rivers, canals, estuaries are being polluted continuously due to unsystematic discharge of wastewater as well as other anthropogenic activities. Thus the reuse of wastewater has become an absolute necessity (Sivasangari et al., 2016).

Electroplating is one of the several techniques of metal finishing. It is a technique of deposition of a fine layer of one metal on another through the electrolytic process to impart various properties and attributes, such as corrosion protection, enhanced surface hardness, lustre, colour, aesthetics, value addition etc. Electroplating operations form part of largescale manufacturing plants (e.g. automobile, cycle, engineering and numerous other industries) or performed as job-work by small and supplementary units (CPCB, 2008). In India, electroplating industries are mostly characterised by small 
scale units having discrete features like as tiny, familyowned jobber units, practices old and obsolete technologies. The electroplating industries are arranged in unauthorized and unplanned areas with lack of infrastructure. These units are in an area of 10-25 sqm and having unskilled manpower (Upadhyay, 2006). The Electroplating industries use various chemicals and metal salts which creates pollution problems by discharging a large quantity of toxic metallic wastewater. The major pollution in these industries is caused by rinse water, spray losses and solution dumping and leakages (Sivasangari et al., 2016). These industrial processes generate a very huge quantity of wastewater containing heavy metals such as nickel, chromium, zinc and iron that are the elements of major concern. These heavy metals discharged from electroplating units above the standard limits can cause a serious ill effect on the environment and human health (Raju et al., 2019). Analytical facilities are not easily accessible to these units, resulting in a lack of control on process parameter and improper documentation of production details. Keeping this in view, the main objective of the present study was to evaluate the monthly variation in $\mathrm{pH}$ and heavy metal concentration in untreated wastewater of selected Electroplating industries of Chandigarh.

\section{MATERIALS AND METHODS}

\section{Study area}

Geographically, the industrial area of Chandigarh is located within latitude $30^{\circ} 44^{\prime} 14 \mathrm{~N}$ in the north to longitude $76^{\circ} 47^{\prime} 14 \mathrm{E}$ in the east. It has an average elevation of 321 meters (1053 ft) above mean sea level. The In- dustrial Area of phase I and II has a vast expanse of about 485.62 hectares with more than 3500 independent industrial units in operation along with a number of electroplating industrial units installed and their treated and untreated or partially treated waste effluents are discharged into the Sukhna Choe (receiving water body) which further mixes with River Ghaggar. The electroplating units are operated in small areas near to 2000 Sq. ft and have their own effluent treatment plant (ETP). Sometimes electroplating industries discharge their effluent without treatment or partially treated wastewater and cause metallic pollution in the receiving water bodies. In view of numerous electroplating industries in this area, the Study sites of ten electroplating industries were selected as Site-1 (SS-1), Site-2 (SS2), Site-3 (SS-3), Site-4 (SS-4), Site-5 (SS-5), Site-6 (SS-6), Site-7 (SS-7), Site-8 (SS-8), Site-9 (SS-9) and Site-10 (SS-10) (Fig.1). The operational unit description of selected electroplating industries in Chandigarh is shown in Table 1.

\section{Sampling procedure}

The three-grab samples of untreated electroplating industrial wastewater post-manufacturing operation and prior to any treatment from each electroplating sites of Chandigarh were collected during each month from July 2019 to September 2020. Due to COVID 19, as an announcement of the country lockdown (April, May, and June) during the year 2020, the sampling of the lockdown period was completed in the month of July, August, and September for the year 2020. All the samples were collected in sufficient quantity $(1000 \mathrm{ml})$ in a non-reactive plastic bottle preserved by adding $\mathrm{HNO}_{3}$ and brought to the laboratory.

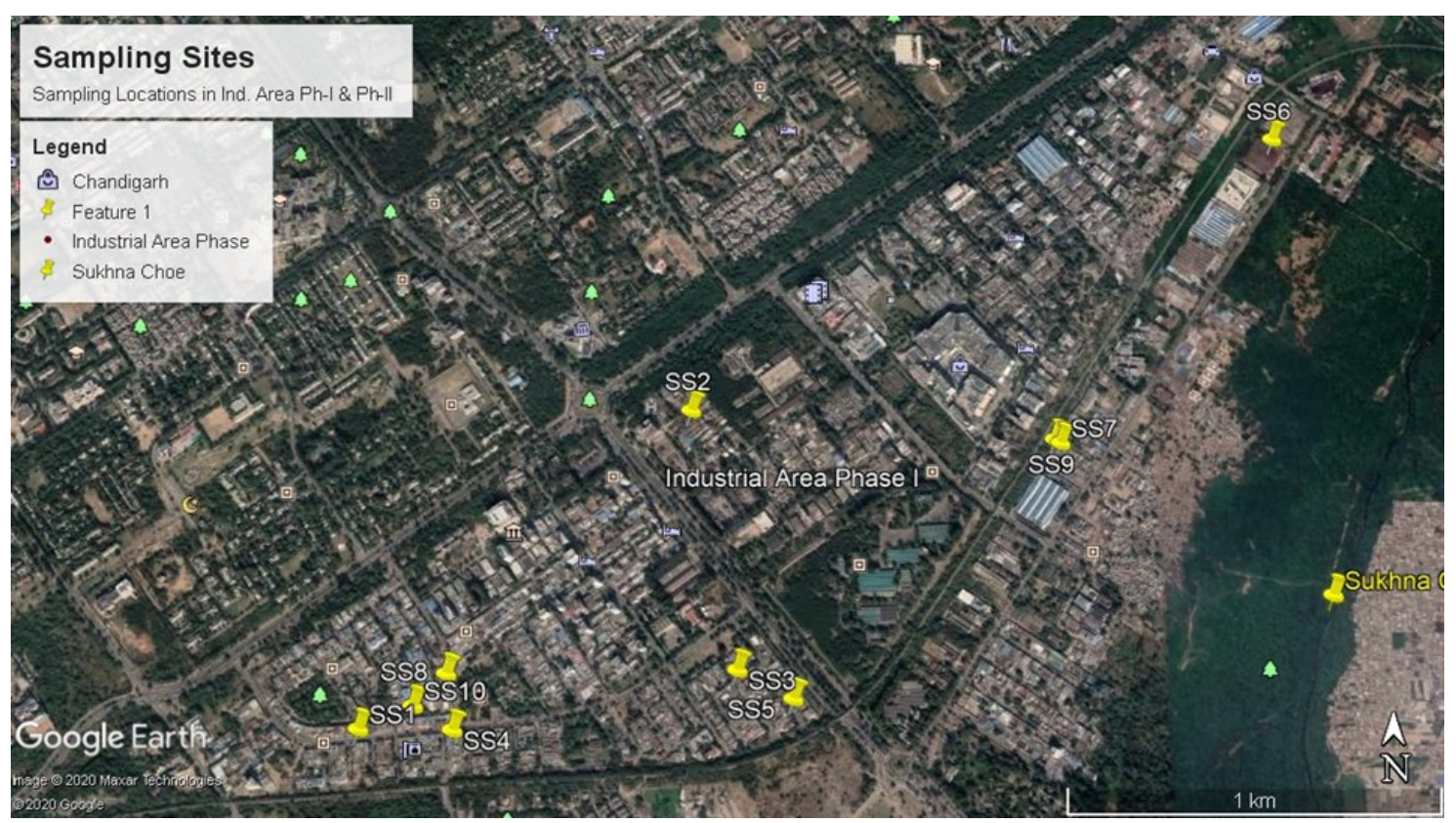

Fig. 1. Showing location of sampling Sites (SS1 to SS 10) of Electroplating industries in Chandigarh. 
Pandey, V. and Rattan, V. K. / J. Appl. \& Nat. Sci. 13(1): 250 - 257 (2021)

Table 1. Description of operating units of selected Electroplating industries in Chandigarh.

\begin{tabular}{lllll}
\hline $\begin{array}{l}\text { Study sites } \\
\text { (SS) }\end{array}$ & $\begin{array}{l}\text { Area } \\
\text { (Sq. Ft.) }\end{array}$ & $\begin{array}{l}\text { Type of } \\
\text { Electroplating }\end{array}$ & $\begin{array}{l}\text { Name of } \\
\text { Electroplating unit }\end{array}$ & $\begin{array}{l}\text { Manufacturing } \\
\text { process }\end{array}$ \\
\hline SS-1 & 4100 & Zn Plating & Atul Industries & Screw Manufacturing Unit \\
SS-2 & 4100 & Zn Plating & $\begin{array}{l}\text { Suresh Fasteners } \\
\text { Bajrang Industrial } \\
\text { Company }\end{array}$ & $\begin{array}{l}\text { Screw Manufacturing Unit } \\
\text { Sob Work of Electroplating }\end{array}$ \\
SS-4 & 2000 & Zn Plating & Stylex Industries & Modular Kitchen Items Manufacturing \\
SS-5 & 5500 & Ni-Cr Plating & Karan Industries & Taps and Screw Manufacturing Unit \\
SS-6 & 2000 & Ni-Cr Plating & Avon Industries & Cycle Rims Manufacturing Unit \\
SS-7 & 43560 & Zn Plating & Geetika Enterprises & Screw and Rivets Manufacturing Unit \\
SS-8 & 2000 & Zn Plating & Atop Fasteners & Tractor Parts Pins Spring Washer \\
SS-9 & 5500 & Zn Plating & Accufit Fasteners & $\begin{array}{l}\text { Job Work of Electroplating } \\
\text { SS-10 }\end{array}$ \\
\hline
\end{tabular}

\section{Analytical methods}

$\mathrm{pH}$ of samples was estimated by the digital $\mathrm{pH}$ meter (Orion Star pH/ISE Meter). For heavy metal analysis, all the collected samples were digested by nitric acid digestion method as described in APHA (2017). Heavy metals concentration in digested samples was estimated by atomic absorption spectrophotometer (Analytic Jena, Model- Zeenit 700P) by running three replicates of each sample. For the standardization process, the calibration curves were prepared separately for all the metals by running different concentrations of standard solutions prepared from Certified Reference Materials (CRMs). A standard solution was run as a reference throughout the analysis of heavy metals. The observed data of three-monthly samplings subjected to statistical analysis for the mean, standard deviation (SD) and was calculated using MS Excel 2010.

\section{RESULTS AND DISCUSSION}

The mean $\pm S D$ values of $\mathrm{pH}$ and various heavy metals of the Electroplating industries during July 2019 to September 2020 are given in Table 2 to 6 .

\section{pH Value}

Variations in $\mathrm{pH}$ of electroplating wastewater were found in the range from 4.4 -5.81 of all study sites (SS1 to SS-10) and are shown in Table. 2. It was found that the minimum $\mathrm{pH}$ of electroplating wastewater was $4.4 \pm 0.30$ at SS-9 in the month of November 2019 while the maximum $\mathrm{pH}$ was $5.81 \pm 0.38$ at the $\mathrm{SS}-2$ in the month of October 2019.It indicated that the observed values of $\mathrm{pH}$ were acidic in nature and were not in the range of discharge standard (6.0-9.0) given by the MOEF, 2012 in all the study sites of the Electroplating industries of Chandigarh. Lokhande et al.(2011) ob- served the 5.2 to $8.7 \mathrm{pH}$ of the effluents discharged from the Taloja industrial area in Mumbai, India. Adakole and Abolude (2009) reported the $\mathrm{pH} 1.70$ 11.80 of the effluents discharged from industrial units involved in metal finishing works at Zaria, Nigeria. $\mathrm{pH}$ affects the quality of wastewater, and any value higher or lower than 6.5-8.5 limit could be harmful to the environment as per WHO (2003).

\section{Zinc (Zn)}

The maximum value of $\mathrm{Zn}(122.20 \pm 2.38 \mathrm{mg} / \mathrm{l})$ was observed at the SS-8 in the month of August 2019, while the minimum value of $\mathrm{Zn}(3.89 \pm 1.66 \mathrm{mg} / \mathrm{l})$ was recorded at SS-10 in the month of March 2020 (Table 3). As seen in Table 3, the reported values of $\mathrm{Zn}$ from all the study sites SS-1 to SS-10 without any treatment was found beyond the discharge limit $(5 \mathrm{mg} / \mathrm{l})$ of MOEF, 2012 standard, while during the month of February and March 2020, the concentration of $\mathrm{Zn}$ was found below the MOEF, 2012 standard limit $(5 \mathrm{mg} / \mathrm{l})$ at the SS-10. Kumar and Thatheyus (2013) reported that the concentration of $\mathrm{Zn}$ (739 mg/l) was found exceedingly beyond the permissible limit of discharged standards of effluents from electroplating units at Madurai, India. Singh et al.(2016) observed that the concentration of zinc varied from 97 to $731 \mathrm{mg} / \mathrm{l}$ across the Haryana region while the concentration of zinc was found $118 \mathrm{mg} / \mathrm{l}$ in the Chandigarh region, which was found beyond the acceptable limit of $5 \mathrm{mg} / \mathrm{l}$.

\section{Nickel (Ni)}

The maximum concentration of $\mathrm{Ni}(156.37 \pm 9.36)$ was recorded at the SS-4 in the month of August 2019 however, the minimum concentration of $\mathrm{Ni}(0.77 \pm 0.20)$ was found the SS-1 in the month of February 2020. As depicted in table 4 all the measured values of $\mathrm{Ni}$ were 
Pandey, V. and Rattan, V. K. / J. Appl. \& Nat. Sci. 13(1): 250 - 257 (2021)

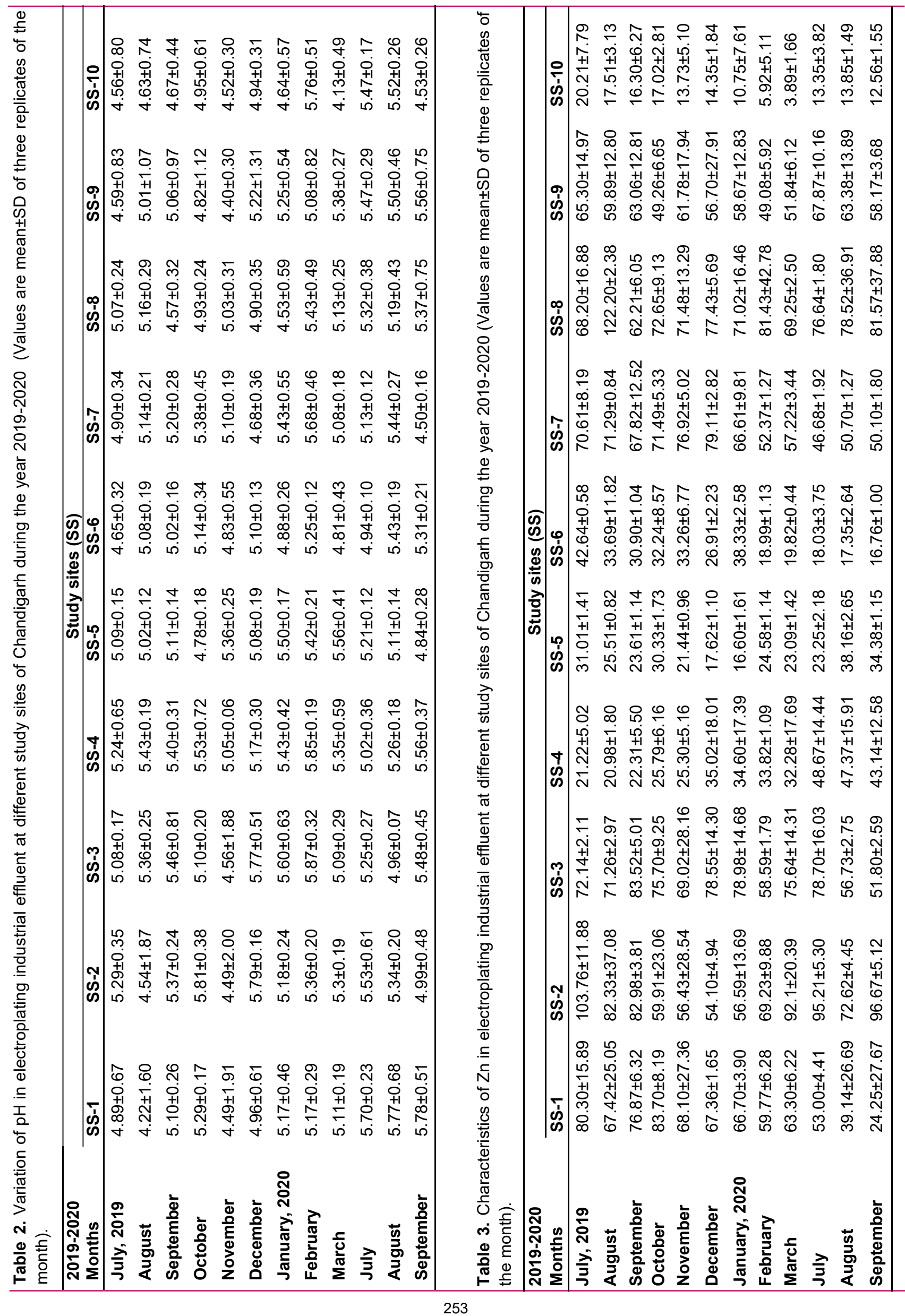


observed higher at the SS-4, SS-5, SS-6 and SS-10 than the discharge limit of MoEF i.e. $3 \mathrm{mg} / \mathrm{l}$, as these sites are the $\mathrm{Ni}$ and chromium plating sites as given in table 4. The concentration of $\mathrm{Ni}$ was found below the MoEF (3 mg/l) standard limit at the SS-1, SS-2, SS-3, SS-7, SS-8 and SS-9, while the concentration of Ni was found beyond the standard limit in the month of September, October and December at the SS-2. As per results reported by Singh et al., (2016), the concentration of $\mathrm{Ni}$ was found from 68 to $291 \mathrm{mg} / \mathrm{l}$ in the effluent of electroplating industries of the Haryana region (Faridabad, Gurgaon, Yamunanagar, Karnal, Jagadhri, Panchkula, Panipat, Ambala and Sirsa) and Chandigarh. It was also observed that the minimum value of $\mathrm{Ni}$ $(68 \mathrm{mg} / \mathrm{l})$ was found in the effluent of electroplating industries of Gurgaon while the maximum value of $\mathrm{Ni}$ (291 mg/l) was found in the effluent of electroplating industries of Ambala. Dermentzis (2010) observed that nickel is the one of hazardous heavy metal in electroplating wastewater as only $30-40 \%$ of nickel can be utilized in the product while $60-70 \%$ unused $\mathrm{Ni}$ is discharged into the water environment as waste effluent. Sanyaolu et al. (2013) reported that the concentration of nickel $(0.093 \mathrm{mg} / \mathrm{l})$ was beyond the standard limit prescribed by WHO (2003) in the effluent of FMCG products manufacturing industry at Ikorodu, Lagos State, Nigeria.

\section{Chromium (Cr)}

The maximum concentration of $\mathrm{Cr}(467.01 \pm 247.13)$ was recorded at SS-5 in October 2019, while the minimum concentration of $\mathrm{Cr}(2.34 \pm 0.76)$ was found in the SS-1 in December 2019, which was higher than the discharge limit of MOEF, $2012(2 \mathrm{mg} / \mathrm{l})$ standard at all the study sites of Chandigarh (Table 5). Singh et al. (2016) studied the physicochemical characterization of electroplating industrial effluents and reported the concentration of $\mathrm{Cr}$ varies from21.5 to $47 \mathrm{ppm}$ in all the Haryana region (Faridabad, Gurgaon, Yamunanagar, Karnal, Panchkula, Panipat, Ambala, Sirsa and Jagadhri) and Chandigarh. Arora et al. (2016) assessed the pollution load at the SIDCUL industrial area and found the concentration of $\mathrm{Cr} 11.264 \mathrm{mg} / \mathrm{l}$, which was exceeded the permissible limit of BIS (2012).

\section{Iron (Fe)}

The maximum concentration of Fe $(13.22 \pm 4.55 \mathrm{mg} / \mathrm{l})$ was observed at the SS-2 in December 2019, while the minimum concentration of $\mathrm{Fe}(0.81 \pm 0.21)$ was found at the SS-5 in August 2020. At the study sites SS-1, SS-4 to SS-10, the concentration of Fe was below the discharge limit of MOEF ( $3 \mathrm{mg} / \mathrm{l})$ standard while the concentration of $\mathrm{Fe}$ was beyond the discharge limit of MOEF (3 mg/l) during February, March, July, August and September 2020 at the SS-1 (Table 6). However, at the SS-2 and SS-3, the concentration of Fe was be-

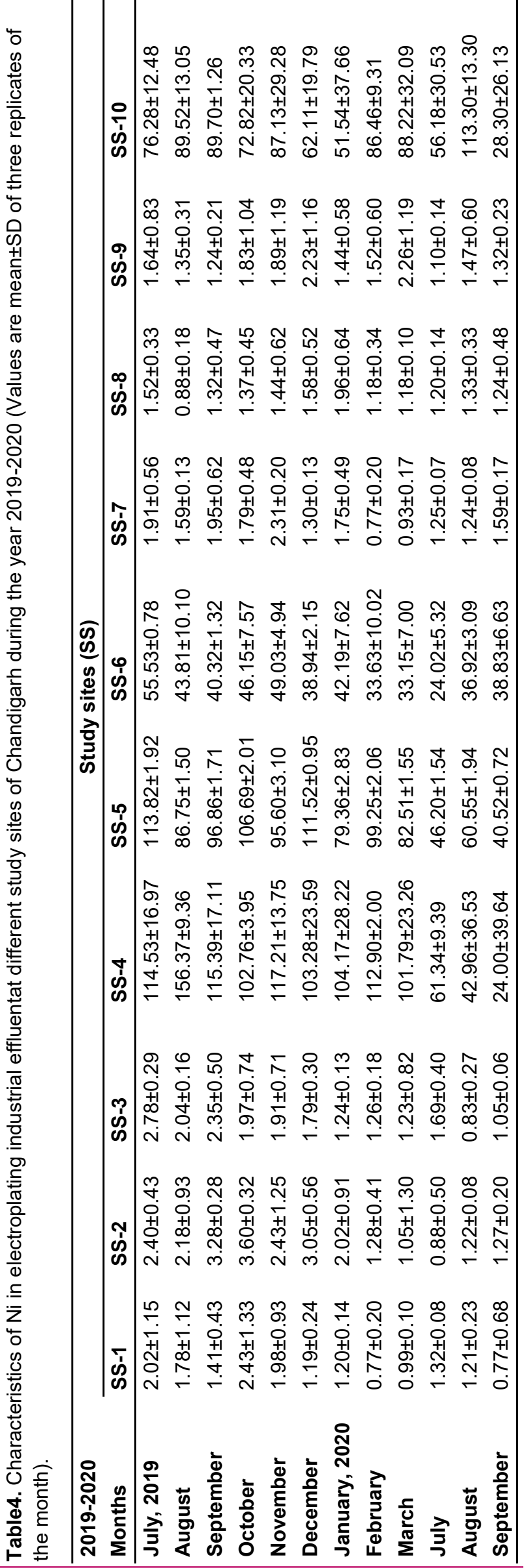


Pandey, V. and Rattan, V. K. / J. Appl. \& Nat. Sci. 13(1): 250 - 257 (2021)

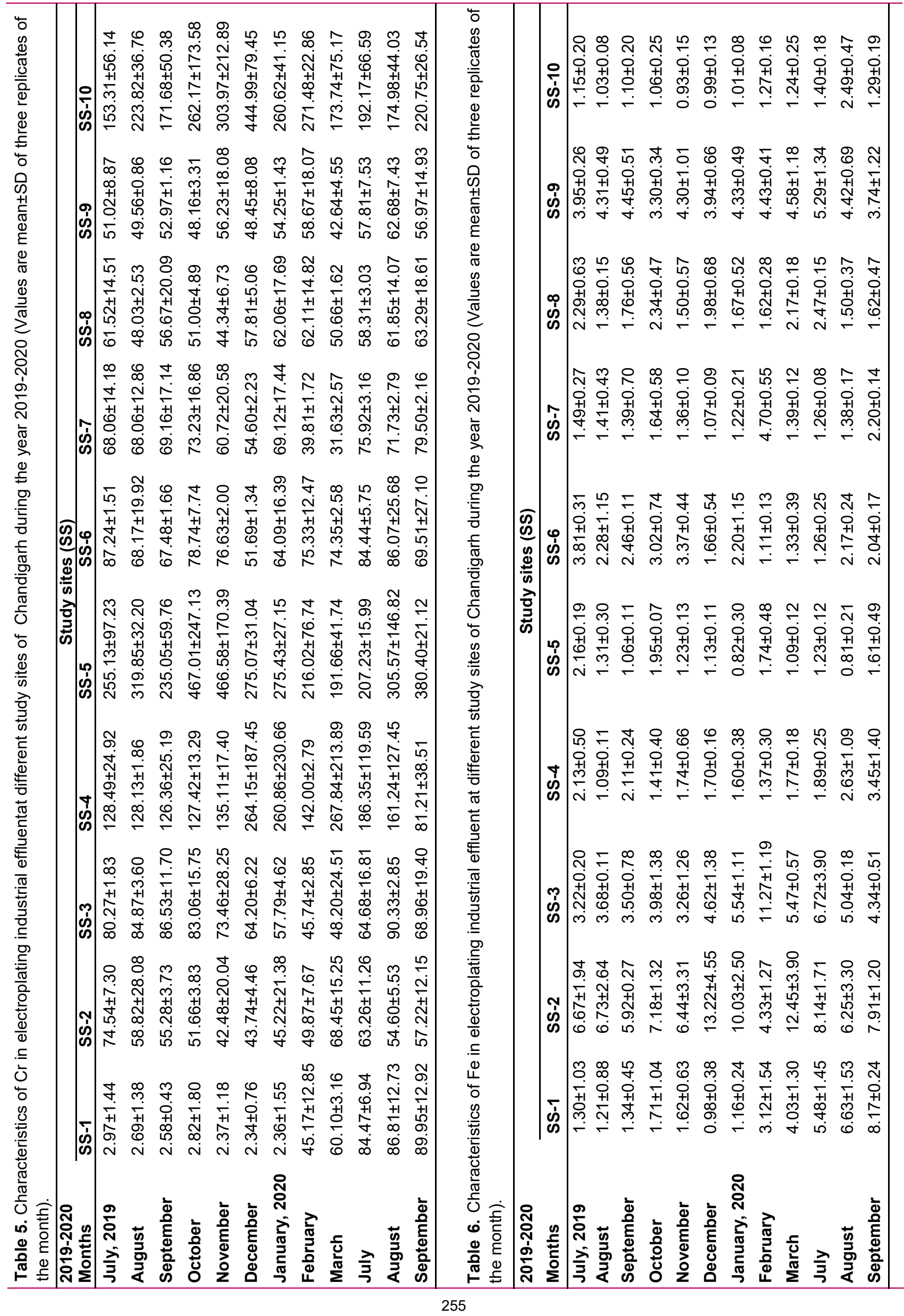


yond the discharge limit of MOEF, 2012 (3 mg/l). It was observed that the increase in the productivity of primary producers at the lower concentration; however, at the higher concentration might cause oxidative stress, disrupt cell membrane and even DNA damage, ultimately leading to the death of the organism (Linton et al., 2007; Sinha et al., 2009); Keller et al., 2012). Arora et al. (2016) studied the pollution load assessment and potential environmental risks of composite industrial effluents discharged from SIIDCUL Integrated Industrial Estate, Haridwar (Uttarakhand) and found that the concentration of heavy metals like $\mathrm{Fe}(37.38 \mathrm{mg} / \mathrm{l}), \mathrm{Cr}$ (11.254 mg/l), $\mathrm{Cu}(4.9 \mathrm{mg} / \mathrm{l})$ and $\mathrm{Pb}(2.11 \mathrm{mg} / \mathrm{l})$ was beyond the prescribed permissible limits of BIS (2012). Thus, on the basis of the overall pollution load of the metals viz. $\mathrm{Cr}, \mathrm{Ni}, \mathrm{Zn}, \mathrm{Fe}$ in the untreated wastewater of Electroplating Industries, it is very clear that this wastewater has enough pollution potential to badly pollute the receiving water body. Although all of the industries have their own effluent treatment plant but knowingly or unknowingly, sometimes wastewater is discharged without treatment or improper treatment. This may cause a hazardous impact on the aquatic life, environment and human health with reference to heavy metal contamination in receiving water body, i.e. Sukhna Choe, which further mixes into Ghaggar river. As this water is further used for irrigation and in some places it is also used for drinking purpose, it is very important to ensure that wastewater is released, only after proper treatment, from the electroplating industries. Managements of these industries have to work out responsibly to make strategies to find out and remove the deficiencies in the electroplating process as well as the treatment process to ensure the same.

\section{Conclusion}

It was concluded from the present study that the electroplating wastewater discharged from the electroplating industries of Chandigarh without any treatment had very poor quality as per the prescribed standard of MOEF (2012). The study revealed that there was a maximum concentration of heavy metals such as $\mathrm{Zn}$ (122.20 mg/l) during August 2019 at the SS-8, Ni (156.37 mg/l) during August 2019 at the SS-4, Cr (467.01 mg/l) during October 2019 at the SS-5 and Fe (13.22 $\mathrm{mg} / \mathrm{l})$ during December 2019 at the SS-2. The concentration of metallic ions without any treatment were in the order of $\mathrm{Cr}>\mathrm{Ni}>\mathrm{Zn}>\mathrm{Fe}$. The variation in the production process may increase heavy metals concentration in wastewater discharge from the electroplating industries. The improper management of chemical handling may also be the reason for pollution load on the receiving water body by the unskilled workforce in the rinse water, drag-out losses and solution dumping and leakages of chemicals. The present study would help to determine the water quality in terms of heavy metals in electroplating effluent and provide the baseline for further research on the development of treatment strategies for wastewater discharge from electroplating industries and minimizing the effects of heavy metal contamination of receiving water bodies.

\section{Conflict of interest}

The authors declare that they have no conflict of interest.

\section{REFERENCES}

1. Adakole, J.A. and D. S. Abolude (2009). Studies on effluent characteristics of ametal finishing company, ZariaNigeria.Res. J. Environ. Earth Sci.,1, 54-57.

2. APHA (2017). Standard methods of water and wastewater analysis $21^{\text {th }}$ edn. American Public Health Association (APHA), Washington DC

3. Arora, T., A. Mishra, A., Matta, G., Chopra, A. K., Kumar, A., Khanna, D.R. \& Kumar, V.(2016). Pollution load assessment and potential environmental risks of composite industrial effluents discharged from SIIDCUL Integrated Industrial Estate, Haridwar (Uttarakhand), India. Journal of Environmental Biology, 38(2):205-216. DOI: 10.22438/ $\mathrm{jeb} / 38 / 2 / \mathrm{MS}-80$

4. CPCB (2008). Waste minimisation and eco-friendly electroplating processes. Central pollution control board (CPCB), Parivesh, New Delhi.

5. Dermentzis, K. (2010). Removal of nickel from electroplating rinse waters using electrostatic shielding electrodialysis/electrodeionization. Journal of Hazardous Materials, 173(1-3), 647-652. https://doi.org/10.1016/j.jhazmat.200 9.08.133

6. Hashem, A.R. and Abed, K.F. (2002). Arsenic, lead and microorganism in hair and nails of some women from Saudi Arabia. Journal of Medical Science, 2, 82-84.

7. Kanoun-Boulé, M.Vicente, J.A.F., CristinaNabais, C., Prasad, M.N.V.\&Freitas ${ }^{a}$, H. (2009). Ecophysiological tolerance of duckweeds exposed to copper. Aquatic Toxicology,91(1),1-9.https://doi.org/10.1016/j.aquatox.2008.09.009

8. Keller, A.A., Garner, K., Miller, R.J. \&Lenihan, H.S. (2012). Toxicity of nano-zero valent iron to freshwater and marine organisms. PLOS ONE7:e43983. https://doi.o $\mathrm{rg} / 10.1371$ /journal.pone.0043983

9. Kumar, G.S. and A.J. Thatheyus (2013). Bioremediation of chromium nickel and zinc in electroplating effluent byEscherichiacoli.Ann. Rev. Res. Biol.,3, 913-920.

10. Linton, T.K., Pacheco, M.A.W., McIntyre, D.O., Clement, W.H., \& Goodrich-Mahoney J (2007). Development of bioassessment-based benchmarks for iron. Environ. Tox. Chem., 26,1291-1298. https://doi.org/10.1897/06-431.1

11. Lokhande, R.S., Singare, P.U. and Pimple, D.S. (2011). Study on physicochemical parameters of wastewater effluents from Taloja. Industrial Area of Mumbai, India. Int. J. Ecosystem, 1, 1-9 (2011).

12. MoEF (2012). Electroplating industries. Environmental standard. Ministry of Environment \& Forests (MoEF). New Delhi, India

13. Nagarajan N., Gunasekaran P. and Rajendran P. (2014). Impacts of Electroplating industrial effluents on plants, 
potable water and genotoxicity to meristematic cells of onion root tips. The Scitech Journal, 0102

14. Raju, M.V., Rao, L. Neelakanta, Mariadas, K., Kumar, M. S. J. and Babu, S. R. (2019). A study on metals recovery from the waste water effluents in electroplating industry. International Journal of Civil Engineering and Technology, 10(02), 1033-1040

15. Sanyaolu, V.T., A.A.A. Sanyaolu and A. Babayeju (2013). Determination of the physico-chemical parameters of an industrial effluent: A case study of Pz Cussons Plc, Ikorodu, Lagos State. JECR,1,12-20. DOI:10.12966/ JECR.08.01.2013

16. Selhi, A. and Nikhil, S. (2014). A study of electroplating process through experiment and simulation. 5th International \& 26th All India Manufacturing Technology, Design and Research Conference (AIMTDR 2014) December 12th-14th, 2014, IIT, Guwahati, Assam, India

17. Singh V., Ram C, Kumar, A. (2016) Physico-Chemical characterization of electroplating industrial effluents of Chandigarh and Haryana region. J. Civil Environ. Eng., 6, 237. doi:10.4172/2165-784X.1000237

18. Sinha, S., Basant, A., Malik, A. and Singh, K.P. (2009). Iron-induced oxidative stress in a macrophyte: a chemometric approach. Ecotox. Environ. Safe, 72,585-595. https://doi.org/10.1016/j.ecoenv.2008.04.017

19. Sivasangari, S., Suseendhar, S., Suresh kumar K., Vijayaprasath, N. and Thirumurugan, M. (2016). Characteristic study of electroplating and dye industrial effluents. International Journal of Innovative Research in Science, Engineering and Technology, 5(12), DOI:10.15680/ IJIRSET.2016.0512122 20810

20. Upadhyay, K. (2006). Solution for wastewater problem related to electroplating industry: an overview. Jr. of Industrial Pollution Control, 22 (1), 59-66

21. WHO (2003). The World Report: Shaping the future, World Health Organization (WHO), Geneva. 